A N N A L E S

UNIVERSITATIS M A R I A E C URIE-SKŁODOW S K A

LUBLIN - POLONIA

VOL. XXXIII, 2

SECTIO J

2020

Uniwersytet Kazimierza Wielkiego w Bydgoszczy. Wydział Psychologii

KATARZYNA GÓRALSKA, MAŁGORZATA ANNA BASIŃSKA

ORCID: 0000-0001-8243-2146; katarzynagoralskaa@gmail.com ORCID: 0000-0002-6763-8012; basinska@ukw.edu.pl

\title{
Zasoby osobiste a elastyczność w radzeniu sobie ze stresem u osób chorych kardiologicznie*
}

Personal Resources and Flexibility in Coping with Stress in Cardiac Patients

Propozycja Cytowania: Góralska, K., Basińska, M.A. (2020). Zasoby osobiste a elastyczność w radzeniu sobie ze stresem u osób chorych kardiologicznie. Annales Universitatis Mariae Curie-Skłodowska. Sectio J, Paedagogia-Psychologia, 33(2), 221-237. DOI: http://dx.doi.org/10.17951/ j.2020.33.2.221-237.

\section{STRESZCZENIE}

Celem niniejszego badania była analiza związku między zasobami osobistymi (nadzieją na sukces i dobrostanem duchowym) a elastycznością w radzeniu sobie ze stresem u pacjentów chorych kardiologicznie oraz sprawdzenie, czy zasoby osobiste i czas trwania choroby są predyktorami elastyczności w radzeniu sobie ze stresem w tej grupie. Uczestnikami badania było 120 pacjentów kardiologicznych (72 mężczyzn i 48 kobiet) w wieku 29-75 lat. W badaniu wykorzystano Kwestionariusz Nadziei na Sukces (KNS), Wskaźnik Duchowego Dobrostanu oraz Kwestionariusz elastyczności w radzeniu sobie ze stresem (KERS-14). Wyniki pokazują, że występuje istotny statystycznie związek między zasobami osobistymi a elastycznością w radzeniu sobie. Każdy z zasobów osobistych (nadzieja na sukces i dobrostan duchowy) pozytywnie koreluje z każdym wymiarem elastycznego radzenia sobie. Analiza wykazała, że zasoby osobiste odgrywają rolę predykcyjną dla elastyczności w radzeniu sobie ze stresem.

Słowa kluczowe: zasoby osobiste; nadzieja; dobrostan duchowy; elastyczność w radzeniu sobie; chorzy kardiologicznie

* Przygotowanie niniejszego artykułu było możliwe dzięki wsparciu Narodowego Centrum Nauki w ramach projektu nr 2016/21/B/HS6/03786. 


\section{WPROWADZENIE}

Niemal połowa zgonów w Polsce spowodowana jest przez choroby układu sercowo-naczyniowego, nazywane również chorobami układu krążenia (ChUK). Stanowią one najczęstszą przyczynę umieralności w Polsce, znacznie przekraczają bowiem wskaźnik zgonów na skutek schorzeń nowotworowych (Cierniak-Piotrowska, Marciniak, Stańczak, 2015).

Obecnie w etiopatogenezie chorób układu krążenia przypisuje się istotne znaczenie czynnikom psychospołecznym, wśród których najczęściej wyróżnia się przewlekły stres, niski poziom wsparcia społecznego, określone cechy osobowości (typ zachowania A, typ osobowości D) oraz depresję (Strike, Steptoe, 2004; Gil i in., 2006; Shen, Myers, McCreary, 2006). Specyficzne właściwości jednostki mogą nie tylko odgrywać rolę czynników ryzyka, lecz także pełnić funkcję ochronną i pomimo licznych obciążeń wynikających z choroby i jej leczenia ułatwiać radzenie sobie z nimi (Szwajca, 2014). Korzystanie z określonych sposobów zaradczych zależy w dużej mierze od osobistych zasobów, które mogą być źródłem siły w stresującej sytuacji.

\section{ZASOBY OSOBISTE}

W literaturze psychologicznej funkcjonuje wiele różnych definicji zasobów. W szerokim znaczeniu zasoby osobiste obejmują wszystkie właściwości, których celem jest pomoc jednostce $\mathrm{w}$ radzeniu sobie ze stresem oraz przeciwdziałanie negatywnym skutkom działania stresu (Poprawa, 1996; Mudyń, 2003). Zasoby można traktować jako złożony układ osobowościowych, dyspozycyjnych i poznawczych czynników, które stanowią część psychologicznego kontekstu radzenia sobie. Są one relatywnie stałymi dyspozycyjnymi cechami wpływającymi na selektywność procesów oceny poznawczej i radzenia sobie (Moos, Schaefer, 1993; Mróz, 2014).

Zasoby osobiste mają znaczenie w wyborze odpowiednich strategii zaradczych oraz warunkują ocenę wydarzenia - mniejsze zasoby to większe prawdopodobieństwo oceny sytuacji jako stresującej (Heszen-Niejodek, 2000). Do zasobów osobistych zaliczanych jest wiele właściwości osobowościowych, m.in. nadzieja i duchowość (Basińska, 2009).

\section{NADZIEJA}

Okres rozwoju nadziei następuje wraz z przebiegiem rozwoju poznawczego, emocjonalnego i społecznego jednostki (Snyder, 2000). Według Charlesa R. Snydera $(2000,2002)$ rozwój ten trwa od wczesnego dzieciństwa. Procesu myślowego, obejmowanego przez konstrukt nadziei, można uczyć się także w póź- 
niejszych etapach życia. W ujęciu Snydera (2002) nadzieja nie jest stanem emocjonalnym, lecz „poznawczym procesem motywacyjnym” (Łaguna, Trzebiński, Zięba, 2005, s. 8), w którym afekt również odgrywa istotną rolę. Nadzieja bazuje na dwóch przekonaniach: (1) przekonaniu o posiadaniu silnej woli oraz (2) przekonaniu o zdolności do znajdowania rozwiązań i planowania dróg realizacji celu. Siła woli odzwierciedla przekonanie jednostki o własnej zdolności wykorzystania wykreowanych przez nią strategii i możliwości wytrwania na obranej drodze prowadzącej do realizacji celu. Przekonanie o zdolności znajdowania rozwiązań odnosi się do postrzegania siebie jako jednostki zdolnej do generowania jednej lub wielu możliwych dróg (strategii, sposobów, planów) prowadzących do osiągnięcia celu (Snyder, 2000). Dla odróżnienia innych pojęć określanych w literaturze psychologicznej tym samym terminem nadzieja z tej perspektywy ujmowana jest jako nadzieja na sukces, gdyż odnosi się do siły oczekiwania pozytywnych efektów własnych przedsięwzięć (Trzebiński, Zięba, 2003).

Wnioski z licznych badań wskazują, że nadzieja na sukces pełni specyficzną funkcję w radzeniu sobie w sytuacjach trudnych (Trzebiński, Zięba, 2004). Osoby, które prezentują wysoki poziom nadziei na sukces, cechuje elastyczność i zdolność poszukiwania alternatywnego celu, gdy napotykają na przeszkody w realizacji wyznaczonego celu. Osoby charakteryzujące się niskim poziomem nadziei mają poczucie, że utknęły w miejscu i rozmyślając nad swoim położeniem, angażują się w wymyślanie niemal magicznych rozwiązań swojej sytuacji (Snyder, 2002).

\section{DOBROSTAN DUCHOWY}

Obecność elementów duchowych w życiu i kulturze, a także poglądy bazujące na przekonaniu o duchowych predyspozycjach jednostki jako zasobach podmiotowych do efektywnego radzenia sobie ze stresem i budowania dobrostanu psychicznego, są źródłem zainteresowania tematyką duchowości. Psychologiczne ujmowanie duchowości jest zróżnicowane i zależne od założeń teoretycznych badacza. Obecnie autorzy odeszli od dość wąskiego ujmowania duchowości w kontekście wiązania jej z doświadczeniem religijnym. Coraz częściej spotyka się rozumienie duchowości jako: wymiaru osobowości (Piedmont, 1999, 2005; MacDonald, 2000), egzystencjalnej postawy jednostki (Elkins, 2001), postawy wobec życia (Skrzypińska, 2012), schematu poznawczego (McIntosh, 1995; Guthrie, 2001) lub wiązki schematów (Ozorak, 2005). Rosnącym zainteresowaniem badawczym cieszy się również rola duchowości w kształtowaniu zdrowia fizycznego, bazująca na próbie identyfikacji mechanizmów, zgodnie z którymi duchowość ma wpływ na fizyczny wymiar funkcjonowania jednostki (McCollough, Willoughby, 2009). Duchowość, poprzez mechanizmy regulacji emocjonalnej, wydaje się oddziaływać nie tylko na procesy fizjologiczne, lecz także na inne 
czynniki związane z funkcjonowaniem układu odpornościowego i układu krążenia (Masters, 2008; Levenson, Aldwin, 2013).

W psychologii tradycyjnie wskazuje się dwa główne oblicza dobrostanu: hedonistyczny i eudajmonistyczny. Dobrostan eudajmonistyczny ujmuje szczęście jako bazujące na autentycznych wartościach i celach, do których dąży jednostka, natomiast podstawą dobrostanu hedonistycznego jest szczęście człowieka rozpatrywane w kategoriach przyjemności i zadowolenia (Ryff, Singer, 2008; Trzebińska, 2008; Diener, Oishi, Lucas, 2011).

Koncepcją, która powstała w nurcie eudajmonistycznego dobrostanu duchowego i która wpisuje się w tematykę niniejszych badań, jest teoria duchowości przedstawiona przez Bruce'a B. Freya, Thimothy'ego P. Daalemana i Vicky Peyton (2005). W zaproponowanym ujęciu dobrostan duchowy jest rozumiany jako poczucie celowości, sensu i znaczenia własnej egzystencji, którego źródło stanowi transcendentalna siła (Frey i in., 2005). Trudności lub aktualne zmiany w stanie zdrowia uaktywniają procesy gromadzenia, przetwarzania i interpretacji informacji oraz ich włączania w kontekst własnych doświadczeń życiowych (Frey $\mathrm{i}$ in., 2005).

Zasoby osobiste, w szczególności nadzieja pozwalająca oczekiwać pozytywnych efektów w przyszłości oraz dobrostan duchowy ułatwiający nadanie sensu doświadczanym trudnościom, wspierają procesy zaradcze jednostki, a zwłaszcza jedną ich właściwość - elastyczność w radzeniu sobie ze stresem (Piórowska, Banasik, 2015; Sołtys, 2015).

\section{ELASTYCZNOŚĆ W RADZENIU SOBIE ZE STRESEM}

Koncepcja elastyczności w radzeniu sobie ze stresem wprowadza zmiany w rozumieniu zjawiska radzenia sobie. Zmiana perspektywy polega na odejściu od analizowania radzenia sobie z punktu widzenia stylów i strategii oraz zaakcentowaniu jego przebiegu i skuteczności. Elastyczność w radzeniu sobie kładzie nacisk na sposób stosowania strategii, a nie na ich rodzaj. Ważnym aspektem elastyczności w radzeniu sobie ze stresem jest zdolność jednostki do efektywnej zmiany stosowanych strategii radzenia sobie, adekwatnie do wymagań wynikających z doświadczanej sytuacji. Elastyczność w takim rozumieniu jawi się jako właściwość, charakterystyka sposobu, w jaki jednostka radzi sobie z sytuacjami trudnymi. Osoba, która radzi sobie ze stresem bardziej elastycznie, jest skuteczniejsza, co sprzyja lepszej adaptacji (rozpatrywanej z różnych perspektyw: etycznych, zdrowia somatycznego, funkcjonowania społecznego, umiejętności zachowania zasobów zaradczych) (Kato, 2012; Basińska, 2015).

Teoria elastycznego radzenia sobie ze stresem, stanowiąca podstawę prezentowanych badań, nawiązuje do poznawczo-transakcyjnej koncepcji stresu Richarda S. Lazarusa i Susan Folkman. Radzenie sobie ze stresem ujmują oni 
jako proces, którego celem jest skuteczne poradzenie sobie z zaistniałymi obciążeniami. Lazarus i Folkman (1984) wyróżnili trzy rodzaje ocen, występujące po sobie i odpowiadające dynamice przebiegu transakcji stresowej. W obciążającej sytuacji jako pierwsza dokonywana jest ocena jej jako stresującej lub nie (primary appraisal). Kolejnym krokiem jest ocena własnych zasobów zaradczych (secondary appraisal). Po ich zastosowaniu jednostka ocenia skuteczność wykorzystanej strategii (reappraisal) i określa, czy stresująca sytuacja została pomyślnie rozwiązana czy też nadal ma z nią do czynienia. Elastyczne radzenie sobie ze stresem cechuje zmienność, określana za Lazarusem i Folkman (1984) jako zmienność międzysytuacyjna, czyli stosowanie różnych strategii radzenia sobie ze stresem odpowiednio do zmieniających się warunków sytuacyjnych, a także zmienność wewnątrzsytuacyjna, akcentowana przez Tsukasę Kato (2015), związana z oceną zastosowanej strategii radzenia sobie ze stresem jako nieskutecznej.

Ponadto ważnym aspektem elastycznego radzenia sobie ze stresem jest posiadanie bogatego i różnorodnego zasobu strategii zaradczych (poznawczych i behawioralnych), które jednostka umiejętnie dostosowuje do zmieniających się warunków stresogennej transakcji lub odpowiednio do dokonanej oceny skuteczności zastosowanych technik. Kolejnym warunkiem elastyczności w radzeniu sobie jest zdolność jednostki do krytycznej analizy zastosowanych strategii oraz poczynienia refleksji nad ich skutecznością, także w kontekście zachowań w przyszłości (Basińska i in., [w druku]).

\section{CEL BADANIA I HIPOTEZY}

W kontekście powyższych rozważań założono, że pacjenci cierpiący z powodu chorób układu krążenia, cechujący się wyższym poziomem zasobów osobistych - nadziei na sukces i dobrostanu duchowego, będą bardziej elastyczni w radzeniu sobie, co jest szczególnie ważne z powodu dużej dynamiki zmian chorobowych oraz obniżenia jakości ich życia. Ze względu na fakt, że są to choroby przewlekłe, postanowiono sprawdzić znaczenie czasu trwania choroby dla relacji między analizowanymi zmiennymi. Celem niniejszych badań była więc analiza związku między zasobami osobistymi a elastycznością w radzeniu sobie osób chorych kardiologicznie oraz sprawdzenie, czy zasoby osobiste wraz $\mathrm{z}$ czasem trwania choroby są predyktorami elastyczności w zakresie radzenia sobie w tej grupie. W oparciu o dane teoretyczne sformułowano następujące hipotezy:

H1. Występuje pozytywny związek między zasobami osobistymi a elastycznością w radzeniu sobie ze stresem w badanej grupie osób chorych kardiologicznie.

H2. Zasoby osobiste wraz z czasem trwania choroby pełnią funkcję predykcyjną dla elastyczności w radzeniu sobie ze stresem. 


\section{METODY}

W celu zweryfikowania hipotez badawczych zastosowano Kwestionariusz Elastyczności w Radzeniu sobie (KERS-14) autorstwa Małgorzaty A. Basińskiej i współpracowników ([w druku]), służący do pomiaru elastyczności w zakresie radzenia sobie ze stresem. W wersji dla osób dorosłych wyodrębniono trzy podskale: 1) Repertuar, 2) Zmienność oraz 3) Refleksyjność. Osoba badana, która uzyskuje wysokie wyniki w skali Repertuar, jest świadoma posiadania szerokiego zakresu strategii radzenia sobie ze stresem. Uważa się za osobę kompetentną, zdolną znaleźć nowe, odpowiednie sposoby poradzenia sobie w trudnych sytuacjach. Wysoki wynik w skali Zmienność oznacza, że badany wybiera te sposoby poradzenia sobie $\mathrm{z}$ trudnościami, które w danej sytuacji są najbardziej właściwe i efektywne. Negatywna ocena skuteczności zastosowanej strategii powoduje zmianę używanej strategii radzenia sobie. Wysoki wynik w skali Refleksyjność oznacza, że jednostka potrafi zastanowić się nad stosowanymi przez siebie strategiami radzenia sobie, poddać refleksji stosowany sposób w wymiarze wyznawanych przez siebie wartości, a także czasami pogodzić się z trudną sytuacją, w której się znalazła. Kwestionariusz składa się z 14 twierdzeń, do których badany ustosunkowuje się, wybierając jedną z czterech odpowiedzi (od 0 - nigdy nie dotyczy, do 3 - zawsze dotyczy). Im wyższy wynik uzyskuje badany, tym jest bardziej elastyczny w radzeniu sobie ze stresem. Skala uzyskała satysfakcjonujące właściwości psychometryczne. Współczynnik rzetelności $\alpha$ Cronbacha dla podskal Refleksyjność, Repertuar i Zmienność oraz wyniku ogólnego wyniósł kolejno 0,73, 0,96, 0,97 i 0,98 (Basińska i in., [w druku]). Rzetelność w badanej grupie wynosi: dla całości skali - 0,98; dla podskal - od 0,73 do 0,98.

Kwestionariusz Nadziei na Sukces (KNS), w polskiej adaptacji Marioli Łaguny, Jerzego Trzebińskiego i Mariusza Zięby (2005), służy do pomiaru natężenia nadziei i jej komponentów. Kwestionariusz składa się z dwóch podskal: 1) przekonania o posiadaniu silnej woli (Silna Wola) oraz 2) przekonania o własnych kompetencjach (Umiejętność Znajdowania Rozwiązań). Test składa się z 12 twierdzeń (w tym osiem jest diagnostycznych, a cztery - buforowe), do których osoba badana ustosunkowuje się poprzez udzielenie odpowiedzi na ośmiostopniowej skali Likerta. Rzetelność polskiej wersji mierzona współczynnikiem $\alpha$ Cronbacha zawiera się w przedziale $0,76-0,86$ ( Łaguna, Trzebiński, Zięba, 2005). W badaniach własnych współczynniki rzetelności wyniosły odpowiednio: dla siły woli $-0,82$; dla umiejętności znajdowania rozwiązań - 0,89; dla wyniku ogólnego - 0,78.

Zapomocą Wskaźnika Duchowego Dobrostanu(Spiritual Index of Well-Being) Timothy'ego P. Daalemana i Bruce'a B. Freya (2004), adaptowanego obecnie do warunków polskich, określono poziom nasilenia duchowego dobrostanu, ujmowanego jako wymiar jakości życia uwarunkowanej stanem zdrowia. Kwestionariusz składa się z 12 twierdzeń sformułowanych w negatywnej formie, do których 
osoby badane ustosunkowują się na pięciostopniowej skali typu Likerta. Im wyższe wartości, tym większe nasilenie duchowego dobrostanu. Narzędzie składa się z dwóch podskal: 1) samoskuteczności oraz 2) schematu życia. Wersja oryginalna skali cechuje się satysfakcjonującą trafnością i rzetelnością (Daaleman, Frey, 2004; Frey i in., 2005). W polskich badaniach pilotażowych potwierdzono dwuczynnikową strukturę narzędzia oraz jego wysoką rzetelność. Współczynnik rzetelności $\alpha$ Cronbacha dla podskal samoskuteczności i schematu życia oraz dla wyniku ogólnego wyniósł odpowiednio 0,84, 0,87 i 0,86 (Sołtys, 2015). Rzetelność narzędzia w badanej grupie także była zadowalająca - współczynnik $\alpha$ Cronbacha wyniósł 0,92 dla wyniku ogólnego oraz 0,88 i 0,96 dla podskal.

\section{OSOBY BADANE I PROCEDURA BADANIA}

Badaniem objęto 120 osób chorych kardiologiczne, w trakcie leczenia szpitalnego w okresie od kwietnia do września 2017 r. Badania były dobrowolne i anonimowe. Chorzy zostali poinformowani o celu badań i możliwości odmowy udziału na każdym etapie. Zbadano 72 mężczyzn (60\%) i 48 kobiet (40\%). Badani mieli od 29 do 75 lat. Średnia wieku dla mężczyzn wyniosła 56,11 lat (SD =9,24), a dla kobiet $-58,02$ lat $(\mathrm{SD}=8,84)$.

Wśród badanych osób najliczniejszą grupę stanowiły osoby z wykształceniem średnim $(\mathrm{N}=49 ; 41 \%)$ i podstawowym $(\mathrm{N}=32 ; 27 \%)$, wykształcenie zawodowe zadeklarowało 30 osób (25\%), a wyższe - 9 osób (8\%). Większość badanych pozostawała w związkach małżeńskich $(\mathrm{N}=73 ; 61 \%)$. Miejsce zamieszkania badanych było zróżnicowane. Największa liczba badanych zamieszkiwała tereny wiejskie $(\mathrm{N}=48 ; 40 \%)$ i miasta do 400 tys. mieszkańców $(\mathrm{N}=29 ; 24 \%)$. Blisko połowa osób badanych była aktywna zawodowo $(\mathrm{N}=54 ; 45 \%)$. Respondentów cechowało duże zróżnicowanie ze względu na rodzaj choroby przewlekłej. Najwięcej pacjentów cierpiało na nadciśnienie $(\mathrm{N}=36 ; 30 \%)$ i chorobę wieńcową ( $\mathrm{N}=19 ; 16 \%)$ oraz przebyło zawał mięśnia sercowego $(\mathrm{N}=10 ; 8 \%)$. Badani chorowali również na niewydolność serca $(\mathrm{N}=8 ; 7 \%)$, mieli wady serca $(\mathrm{N}=4$; $3 \%)$, zaburzenia rytmu $(\mathrm{N}=7 ; 6 \%)$ i pracy serca $(\mathrm{N}=6 ; 5 \%)$ oraz inne choroby układu sercowo-naczyniowego $(\mathrm{N}=30 ; 25 \%)$. Czas trwania choroby, wskazany przez badanych, także był bardzo zróżnicowany, gdyż oscylował w granicach od 1 miesiąca do 30 lat. Średni okres trwania choroby to 6 lat $(\mathrm{SD}=5,11)$.

\section{WYNIKI}

\section{Charakterystyka wyników średnich}

Charakterystyki średnich wyników zostały dokonane na podstawie statystyk opisowych po odniesieniu ich do norm stenowych. Poziom nasilenia elastyczności 
w radzeniu sobie i jego wymiarów oraz nadziei i jej wymiaru - siły woli - odpowiada piątemu stenowi, czyli wskazuje na przeciętne nasilenie badanych konstruktów. Nasilenie wymiaru umiejętności znajdowania rozwiązań odpowiada stenowi czwartemu (poziom obniżony). Wyniki uzyskane w pomiarze dobrostanu duchowego mieszczą się w pierwszym kwartylu. Nie można ich odnieść do wyników normalizacyjnych, gdyż test nie posiada norm polskich.

Tabela 1. Statystyki opisowe dla mierzonych zmiennych w grupie chorych kardiologicznie $(\mathrm{N}=120)$

\begin{tabular}{|c|c|c|c|c|}
\hline Zmienna & $\mathrm{M}$ & $\mathrm{SD}$ & Min. & Maks. \\
\hline Elastyczność w radzeniu sobie & 20,65 & 10,72 & 0,00 & 42,00 \\
\hline Repertuar & 7,36 & 4,08 & 0,00 & 15,00 \\
\hline Zmienność & 8,64 & 4,94 & 0,00 & 18,00 \\
\hline Refleksyjność & 4,65 & 2,07 & 0,00 & 9,00 \\
\hline Duchowy dobrostan & 43,77 & 6,65 & 24,00 & 60,00 \\
\hline Samoskuteczność & 20,22 & 3,83 & 10,00 & 30,00 \\
\hline Schemat życia & 23,55 & 3,95 & 12,00 & 30,00 \\
\hline Nadzieja na sukces & 43,33 & 7,12 & 27,00 & 60,00 \\
\hline Siła woli & 21,63 & 3,78 & 13,00 & 32,00 \\
\hline $\begin{array}{c}\text { Umiejętność znajdowania } \\
\text { rozwiązań }\end{array}$ & 21,70 & 3,83 & 12,00 & 32,00 \\
\hline
\end{tabular}

M - średnia wyników surowych; SD - odchylenie standardowe wyników surowych; Min. - minimum; Maks. - maksimum

Źródło: opracowanie własne.

\section{Związek między zasobami osobistymi a elastycznością w radzeniu sobie ze stresem}

W hipotezie H1 założono, że zachodzi pozytywny, istotny statystycznie związek między zasobami osobistymi a elastycznością w radzeniu sobie osób chorych kardiologicznie. Dla zweryfikowania hipotezy określono współczynnik korelacji r-Pearsona, gdyż analizowane zmienne miały rozkład zbliżony do normalnego.

W wyniku przeprowadzonych analiz stwierdzono, że występuje istotny statystycznie związek między analizowanymi zasobami osobistymi a elastycznością w radzeniu sobie ze stresem, co pozwala na przyjęcie w całości hipotezy H1. Każdy z zasobów - duchowy dobrostan i nadzieja na sukces - oraz ich wymiary korelują dodatnio z każdym z wymiarów elastyczności w radzeniu sobie. Pacjenci chorzy kardiologicznie cechujący się większym natężeniem zasobów osobistych wykazują większą elastyczność w radzeniu sobie ze stresem.

W celu pogłębienia odpowiedzi na pytanie o związek zasobów osobistych z elastycznym radzeniem sobie ze stresem wykonano analizę skupień (metodą k-średnich). Wyodrębniono dwa skupienia odpowiadające dwóm poziomom 
zasobów osobistych w badanej grupie chorych (rysunek 1). Spośród nich 50 osób (42\%) zaklasyfikowano do podgrupy o większych zasobach, a pozostałych badanych $(\mathrm{N}=69 ; 58 \%)$ - do podgrupy o mniejszych zasobach.

Tabela 2. Zasoby osobiste a elastyczność w radzeniu sobie ze stresem - wskaźniki korelacji r-Pearsona

\begin{tabular}{|c|c|c|c|c|}
\hline \multirow{2}{*}{ Zmienne } & $\begin{array}{c}\text { Elastyczność } \\
\text { w radzeniu sobie }\end{array}$ & Repertuar & Zmienność & Refleksyjność \\
\cline { 2 - 5 } & \multicolumn{4}{|c|}{$r$} \\
\hline Duchowy dobrostan & $0,475^{* * *}$ & $0,484^{* * * *}$ & $0,484^{* * *}$ & $0,441^{* * *}$ \\
\hline Samoskuteczność & $0,503^{* * *}$ & $0,497 * * *$ & $0,497 * * *$ & $0,508^{* * *}$ \\
\hline Schemat życia & $0,312^{* * *}$ & $0,333^{* * *}$ & $0,333^{* *}$ & $0,250^{* *}$ \\
\hline Nadzieja na sukces & $0,637^{* * *}$ & $0,652^{* * *}$ & $0,652^{* * *}$ & $0,491^{* * *}$ \\
\hline Siła woli & $0,552^{* * *}$ & $0,571^{* * *}$ & $0,571^{* * *}$ & $0,454^{* * *}$ \\
\hline $\begin{array}{c}\text { Umiejętność znajdowania } \\
\text { rozwiązań }\end{array}$ & $0,639^{* * *}$ & $0,649 * * *$ & $0,649 * * *$ & $0,464 * * *$ \\
\hline
\end{tabular}

$* \mathrm{p}<0,05 ; * * \mathrm{p}<0,01 ; * * * \mathrm{p}<0,001$

Źródło: opracowanie własne.

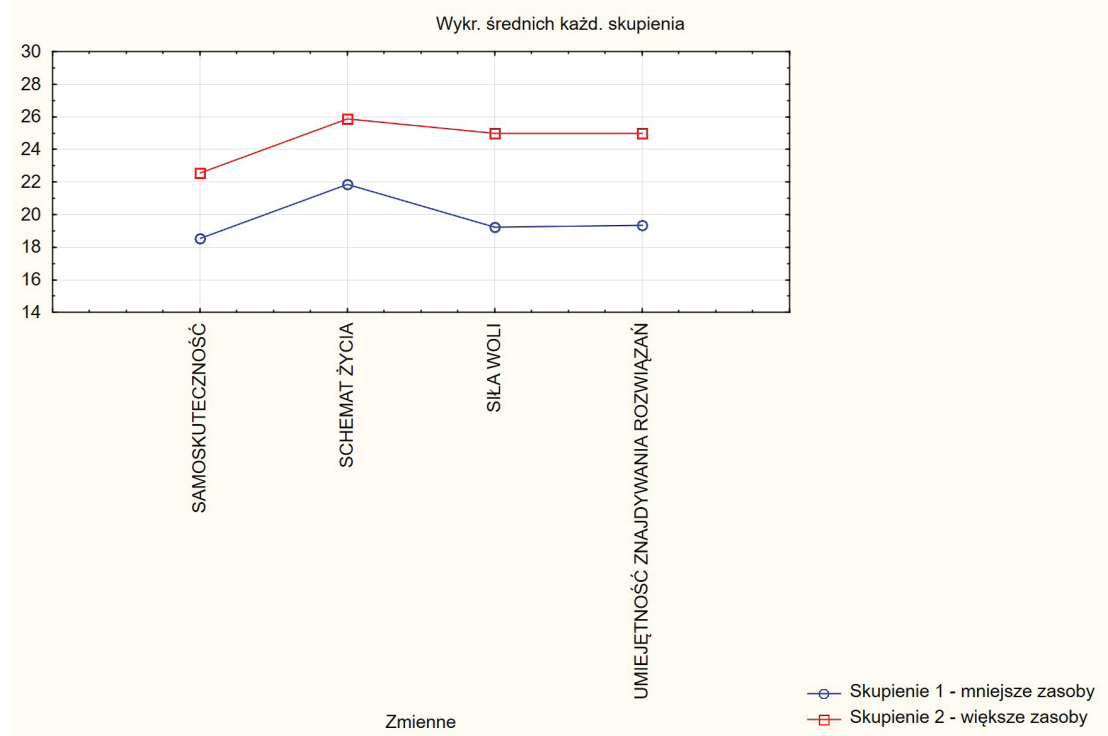

Rysunek 1. Wykres średnich dla zasobów osobistych dla każdego skupienia Źródło: opracowanie własne.

Następnie sprawdzono, na jakim poziomie plasuje się elastyczne radzenie sobie ze stresem w badanych podgrupach (tabela 3 ). 
Tabela 3. Wartość testu U Manna-Whitneya dla elastyczności w radzeniu sobie i dla jej wymiarów

\begin{tabular}{|c|c|c|c|c|c|}
\hline \multirow{2}{*}{ Zmienne } & \multicolumn{2}{|c|}{ Zasoby osobiste } & \multirow{2}{*}{} & \multirow{2}{*}{ U } \\
\cline { 2 - 3 } & $\begin{array}{c}\text { niższe } \\
(\mathrm{N}=69)\end{array}$ & $\begin{array}{c}\text { wyższe } \\
(\mathrm{N}=50)\end{array}$ & $\mathrm{Z}$ & $\mathrm{p}$ \\
\cline { 2 - 3 } & suma rang & suma rang & & & \\
\hline $\begin{array}{c}\text { Elastyczność } \\
\text { w radzeniu sobie }\end{array}$ & 2961,00 & 4179,00 & $-6,35$ & 546,0 & $<0,001$ \\
\hline Repertuar & 2939,00 & 4201,00 & $-6,46$ & 524,0 & $<0,05$ \\
\hline Zmienność & 2931,00 & 4209,00 & $-6,51$ & 516,0 & $<0,05$ \\
\hline Refleksyjność & 3366,50 & 3773,50 & $-4,16$ & 951,5 & $<0,05$ \\
\hline
\end{tabular}

Źródło: opracowanie własne.

Otrzymane wyniki wskazują tylko na pewną tendencję do częstszego stosowania strategii zaradczych w elastyczny sposób, gdy chory posiada więcej zasobów osobistych.

\section{Zasoby osobiste i czas trwania choroby jako predyktory elastyczności w radzeniu sobie}

Aby odpowiedzieć na pytanie, czy zasoby osobiste i czas trwania choroby pełnią funkcję predykcyjną dla elastyczności w radzeniu sobie osób chorych kardiologicznie, zastosowano analizę regresji w wersji grzbietowej.

Tabela 4. Zasoby osobiste i czas trwania choroby jako predyktory elastyczności w radzeniu sobie

\begin{tabular}{|c|c|c|c|c|c|c|c|}
\hline Predyktor & $\mathrm{b}^{*}$ & $\begin{array}{c}\text { Błąd std. } \\
\mathrm{z} \mathrm{b}\end{array}$ & $\mathrm{B}$ & $\begin{array}{c}\text { Błąd std. } \\
\mathrm{z} \mathrm{b}\end{array}$ & $\mathrm{t}$ & $\mathrm{p}$ & $\begin{array}{c}\mathrm{R}^{2} \\
\text { skorygowane }\end{array}$ \\
\hline Czas trwania choroby & $-0,071$ & 0,082 & $-0,150$ & 0,174 & $-0,865$ & 0,389 & \\
\hline Samoskuteczność & 0,286 & 0,088 & 0,826 & 0,254 & 3,258 & 0,002 & \\
\hline Schemat życia & 0,055 & 0,092 & 0,153 & 0,255 & 0,598 & 0,552 & \multirow{2}{*}{0,40} \\
\hline Siła woli & 0,021 & 0,119 & 0,063 & 0,359 & 0,175 & 0,862 & \\
\hline $\begin{array}{c}\text { Umiejętność } \\
\text { znajdowania rozwiązań }\end{array}$ & 0,459 & 0,112 & 1,360 & 0,333 & 4,084 & $<0,001$ & \\
\hline
\end{tabular}

b* - niestandaryzowany współczynnik regresji; B - standaryzowany współczynnik regresji; Błąd std. z b* - błąd standardowy estymacji dla niestandaryzowanego współczynnika regresji; Błąd std. $\mathrm{z}$ b - błąd standardowy estymacji dla standaryzowanego współczynnika regresji; $\mathrm{t}$ - wartość testu t; $\mathrm{p}$ - poziom istotności statystycznej; $\mathrm{R}^{2}$ - współczynnik determinacji (skorygowany)

Źródło: opracowanie własne. 
Analiza wykazała, że zaproponowany model jest istotny statystycznie $(\mathrm{F}(6,92)=11,91 ; \mathrm{p}<0001)$ i wyjaśnia 40\% wariancji. Samoskuteczność (wymiar duchowości) oraz umiejętność znajdowania rozwiązań (wymiar nadziei) pozwalają najsilniej przewidzieć elastyczność w radzeniu sobie ze stresem u osób chorych kardiologicznie oraz są istotnymi predyktorami zmiennej zależnej - elastyczności w radzeniu sobie. Na podstawie wyższego poziomu zasobów, a w szczególności wyższej samoskuteczności i umiejętności znajdowania rozwiązań, można przewidywać, że badani chorzy będą bardziej elastyczni w radzeniu sobie ze stresem. Czas trwania choroby nie okazał się istotnym predyktorem elastyczności w radzeniu sobie ze stresem. Można zatem przyjąć hipotezę H2 jedynie w części.

\section{DYSKUSJA}

Z punktu widzenia współczesnej psychologii zdrowia zasadne jest poszukiwanie czynników chroniących przed chorobami układu sercowo-naczyniowego, gdyż schorzenia te nadal są główną przyczyną przedwczesnej umieralności wśród mężczyzn i kobiet w Polsce. Wyniki badań natomiast ukazują coraz większe znaczenie właściwości psychospołecznych dla rozwoju i przebiegu tych chorób (Opuchlik, Wrzesińska, Kocur, 2009; Boehm, Peterson, Kivimaki, Kubzansky, 2011; Lambiase, Kubzansky, Thurston, 2015). Specyficzne właściwości człowieka pełnią funkcje ochronne i mimo licznych obciążeń oraz kumulujących się stresorów pomagają w konstruktywnym radzeniu sobie z trudnościami życiowymi (Szwajca, 2014), utrzymaniu dobrostanu psychicznego (Boehm i in., 2011) oraz przeciwdziałaniu negatywnym skutkom stresu (Poprawa, 1996; Mudyń, 2003). Elastyczność w radzeniu sobie ze stresem jest zdolnością, która pełni taką funkcję. Składają się na nią: przekonanie o posiadaniu wystarczających kompetencji do poradzenia sobie z trudnościami, umiejętność stosowania odpowiednich do sytuacji strategii oraz gotowość jednostki do zastanowienia się nad stosowanymi przez siebie strategiami radzenia sobie (Basińska i in., [w druku]).

W wyniku przeprowadzonych analiz stwierdzono, że występuje istotny statystycznie związek między zasobami osobistymi a elastycznością w radzeniu sobie. Każdy z zasobów osobistych i ich wymiarów koreluje dodatnio z każdym $\mathrm{z}$ wymiarów elastyczności w radzeniu sobie. Związek tych zmiennych znajduje potwierdzenie m.in. w podstawach teoretycznych rozpatrywanych konstruktów, a także w teorii zachowania zasobów Stevana E. Hobfolla (1989), która powstała jako propozycja wyjaśnienia zachowania osoby w sytuacji stresu. Według założeń teorii zachowania zasobów ogólnym celem aktywności człowieka jest zdobywanie, utrzymywanie i ochrona zasobów, które mogą być ujmowane bardzo szeroko, włączając w to zasoby osobiste, w formie pozytywnych przekonań na temat samego siebie i świata. Jednostki posiadające zróżnicowane i bogate zasoby osobiste skuteczniej radzą sobie z aktualnymi wyzwaniami, stresem i utratą 
zasobów, nie tylko łatwiej znoszą porażki, lecz także są zdolne do rozwoju i poprawy funkcjonowania oraz są w stanie podejmować nowe wyzwania. Stanowi to wyjaśnienie dla wniosków z przeprowadzonych badań, w których wykazano, że osoby cechujące się większym natężeniem zasobów osobistych różnią się istotnie od osób o mniejszym natężeniu zasobów osobistych pod względem elastyczności w radzeniu sobie. Badania wykazały, że osoby z wyższym poziomem nadziei mają większe zdolności adaptacyjne do sytuacji trudnych, a w sytuacjach straty wykazują większą gotowość do zaangażowania w budowę nowego porządku. Jednostki takie również częściej reagują na trudne sytuacje konstruktywnym długookresowym rozwojem osobowości (Łaguna i in., 2005). Osoby charakteryzujące się wysokim poziomem nadziei na sukces, gdy napotykają przeszkody w realizowanym zadaniu, są bardziej elastyczne i potrafią znaleźć alternatywny cel. Osoby o niskiej nadziei mają tendencję do wyobrażania sobie magicznych rozwiązań, co najczęściej jest nieefektywne i wiąże się z ich pasywnością (Snyder, Pulvers, 2001). Nadzieja na sukces odgrywa ważną rolę w różnych obszarach życia, w tym w zakresie przystosowania. Badania przeprowadzone na studentach i pacjentach leczonych psychiatrycznie wykazały, że wyższy poziom nadziei jest związany z lepszym ogólnym przystosowaniem (Kwon, 2002). Wywnioskowano, że nadzieja koreluje z radzeniem sobie ze stresem (Snyder, 2002). Postawa pełna nadziei sprawia, że jednostka w sposób bardziej efektywny radzi sobie z przeciwnościami życiowymi i stosuje bardziej adaptacyjne formy radzenia sobie oraz przejawia wyższy poziom dobrostanu (Carr, 2009).

Wyniki badań wskazują, że także duchowość pełni ważne funkcje regulacyjne, a tym samym decyduje m.in. o percepcji zdrowia oraz jego obiektywnym stanie (Koening, 2008; Masters, 2008), a także wpływa na procesy fizjologiczne oraz na inne czynniki związane z działaniem układu immunologicznego i układu krążenia (Masters, 2008; Levenson, Aldwin, 2013). W literaturze przedmiotu podkreśla się kluczową rolę duchowości i/lub religijności w mechanizmie kształtowania zdrowia, uwzględniając również psychologiczne i behawioralne komponenty (Koening, 2008; Masters, 2008; Nelson, 2009; Krause, 2011; Park, 2012). Badania Katherine E. Adelstein, Joela G. Andersona i Ann G. Taylor (2014) wykazały, że nadawanie i rozumienie znaczenia stanowi istotny aspekt adaptacyjnego radzenia sobie i przezwyciężania fizycznych, psychospołecznych i duchowych wyzwań. W ujęciach teoretycznych zasoby traktowane są jako czynnik ułatwiający pozytywną adaptację do sytuacji choroby przewlekłej. Pomagają one wprowadzić pozytywne zmiany w życiu, głównie o charakterze behawioralnym, polegającym na zmianie stylu życia (Bergman, Bertero, 2003; Łuszczyńska, Cieślak, 2009). Zasoby osobiste i społeczne ułatwiają więc przystosowanie się do krytycznych wydarzeń i sytuacji życiowych oraz zwiększają skuteczność radzenia sobie z sytuacjami stresowymi.

Prezentowane analizy wykazały, że zasoby osobiste pełnią funkcję predykcyjną dla elastyczności w radzeniu sobie ze stresem. Samoskuteczność oraz 
umiejętność znajdowania rozwiązań pozwalają najsilniej przewidzieć elastyczność w radzeniu sobie ze stresem w badanej grupie osób chorych kardiologicznie. Wymiar umiejętności znajdowania rozwiązań cechuje postrzeganie własnej osoby jako zaradnej, zdolnej do opracowania różnych dróg osiągnięcia założonego celu (Snyder, 2002). Wynik ten pozostaje w związku z tezą, jaką wysunęli Charles S. Carver i Michael F. Scheier (2002), zgodnie z którą nadzieja na sukces jest szczególnie istotna $\mathrm{w}$ sytuacjach, kiedy zachodzi potrzeba podjęcia działań czy interwencji. Osoba radząca sobie elastycznie potrafi zaprzestać stosowania nieefektywnych strategii radzenia sobie oraz wykreować i zastosować alternatywne strategie, dlatego umiejętność znajdowania rozwiązań w sytuacji stresowej jako cecha nadziei pomaga jednostce być bardziej elastyczną w procesie radzenia sobie (Basińska i in., [w druku]). Warto zwrócić uwagę, że w analizowanym konstrukcie elastyczności występuje ważny element, jakim jest repertuar posiadanych strategii, który podobnie jak wymiar umiejętności znajdowania rozwiązań opisuje jednostki przekonane o swoich możliwościach zaradczych. Wynik dotyczący predykcyjnej roli samoskuteczności dla elastyczności w radzeniu sobie pozostaje zbieżny z badaniami wskazującymi, że osoby przejawiające wyższe poczucie samoskuteczności w obszarze duchowości będą także sprawniej adaptować się w innych obszarach życia (por. Oman i in., 2012). Zasoby osobiste, w szczególności nadzieja pozwalająca oczekiwać pozytywnych efektów w przyszłości oraz dobrostan duchowy ułatwiający nadanie sensu doświadczanym trudnościom, wspierają procesy zaradcze jednostki, a zwłaszcza jedną ich właściwość - elastyczność (Piórowska, Bansik, 2015; Sołtys, 2015).

Na podstawie wyników badań można stwierdzić, że czas trwania choroby nie jest istotnym predyktorem elastyczności w radzeniu sobie ze stresem. Dotychczasowe wyniki (Basińska, Rusek, 2015; Kruczek, Basińska, Grzankowska, 2019) wskazują na podłoże temperamentalno-osobowościowe elastyczności w radzeniu sobie, stąd można wnioskować o względnej stałości wykształconej elastyczności, również niezależnej od czynników sytuacyjnych (w opisywanych badaniach - okresu trwania choroby).

Ograniczenie wynikające z przedstawionych analiz dotyczy głównie sposobu zbierania danych. Anonimowość nie pozwoliła na zróżnicowanie grupy pod kątem zdiagnozowanych chorób kardiologicznych. Ten sposób zbierania danych był optymalny dla zachowania całkowitej anonimowości, ale jednocześnie spowodował, że próba badana nie była próbą losową, ponieważ kwestionariusze wypełniły tylko osoby zainteresowane.

Pomimo ograniczeń uzyskane wyniki badań wnoszą nowe informacje w obszar zagadnienia dotyczącego uwarunkowań elastyczności w radzeniu sobie ze stresem osób chorych kardiologicznie. Potwierdzają również znaczny wpływ zasobów osobistych na funkcjonowanie jednostki. Te rezultaty mogą mieć także znaczenie praktyczne, przede wszystkim w procesie adaptacji do choroby. Podkreślają ponadto potrzebę 
rozwijania i kształtowania zasobów osobistych. Zasoby osobiste można rozwijać poprzez pobudzanie wysokiej motywacji do podejmowania nowych działań czy zmiany zachowań, m.in. dzięki kształtowaniu poczucia własnej wartości i skuteczności, duchowości, kreatywności, niezależności czy elastyczności (Czapiński, 2002).

\section{WNIOSKI}

1. Występuje pozytywny związek między zasobami osobistymi a elastycznością w radzeniu sobie ze stresem w badanej grupie osób chorych kardiologicznie.

2. Osoby o większym ogólnym natężeniu zasobów osobistych w porównaniu do osób o mniejszym ogólnym natężeniu zasobów osobistych cechują się większą elastycznością w radzeniu sobie ze stresem.

3. Zasoby osobiste pełnią funkcję predykcyjną dla elastyczności w radzeniu sobie ze stresem. Samoskuteczność oraz umiejętność znajdowania rozwiązań pozwalają najsilniej przewidzieć elastyczność w radzeniu sobie ze stresem u osób chorych kardiologicznie. Okres trwania choroby nie jest istotnym predyktorem elastyczności w radzeniu sobie ze stresem.

\section{BIBLIOGRAFIA}

Adelstein, K.E., Anderson, J.G., Taylor, A.G. (2014). Importance of meaning-making for patients undergoing hematopoietic stem cell transplantation. Oncology Nursing Forum, 41(2), 172-184. DOI: https://doi.org/10.1188/14.ONF.E172-E184

Basińska, M.A. (2009). Funkcjonowanie psychologiczne pacjentów w wybranych chorobach endokrynologicznych. Bydgoszcz: Wydawnictwo UKW.

Basińska, M.A. (2015). Polska wersja Skali Elastycznego Radzenia Sobie - podsumowanie wyników badań. W: M.A. Basińska (red.), Coping Flexibility with Stress in Health and in Disease. Elastyczne radzenie sobie ze stresem $w$ zdrowiu $i w$ chorobie (s. 273-294). Bydgoszcz: Wydawnictwo UKW.

Basińska, M.A., Rusek, A. (2015). Temperament and coping flexibility in a group of art students. W: M.A. Basińska (red.), Coping Flexibility with Stress in Health and Indisease. Elastyczne radzenie sobie ze stresem w zdrowiu i w chorobie (s. 117-132). Bydgoszcz: Wydawnictwo UKW.

Basińska, M.A., Kruczek, A., Borzyszkowska, A., Góralska, K., Grzankowska, I., ..., Sołtys, M. ([w druku]). Flexibility in Coping with Stress Questionnaire: Structure and Psychometric Properties. International Journal of Occupational Medicine and Environmental Health.

Bergman, E., Bertero, C. (2003). "Grasp life again". A qualitative study of the motive power in myocardial infarction patients. European Journal of Cardiovascular Nursing, 2(4), 303-310. DOI: https://doi.org/10.1016/S1474-5151(03)00098-7

Boehm, J.K., Peterson, Ch., Kivimaki, M., Kubzansky, L. (2011). A prospective study of positive psychological well-being and coronary heart disease. Health Psychology, 30(3), 259-267. DOI: https://doi.org/10.1037/a0023124

Carr, A. (2009). Psychologia pozytywna. Nauka o szczęściu i ludzkich siłach. Poznań: Zysk i S-ka. Carver, Ch.S., Scheier, M.F. (2002). The hopeful optimist. Psychological Inquiry, 13(4), 288-290.

Cierniak-Piotrowska, M., Marciniak, G., Stańczak, J. (2015). Statystyka zgonów i umieralności z powodu chorób układu krążenia. W: Z. Strzelecki, J. Szymborski (red.), Zachorowalność 
i umieralność na choroby układu krążenia a sytuacja demograficzna Polski (s. 46-81). Warszawa: Rządowa Rada Ludnościowa.

Czapiński, J. (2002). Szczęśliwy człowiek w szczęśliwym społeczeństwie? Zrównoważony rozwój, jakość życia i złudzenie postępu. Psychologia Jakości Życia, 1(1), 9-34.

Daaleman, T.P., Frey, B.B. (2004). The Spirituality Index of Well-Being: A new instrument for health-related quality of life research. Annals of Family Medicine, 2(5), 499-503.

DOI: https://doi.org/10.1370/afm.89

Diener, E., Oishi, S., Lucas, R.E. (2011). Subjective well-being: The science of happiness and life satisfaction. W: S.J. Lopez, Ch.R. Snyder (eds.), The Oxford Handbook of Positive Psychology (s. 187-194). Oxford: Oxford University Press.

Elkins, D.N. (2001). Beyond religion: toward a humanistic spirituality. W: K.J. Schneider, J.T. Bugental, J.F. Pierson (eds.), The Handbook of Humanistic Psychology: Leading Edges in Theory, Research, and Practice (s. 201-212). Thousand Oaks: Sage.

Frey, B.B., Daaleman, T.P., Peyton, V. (2005). Measuring a dimension of spirituality for health research: Validity of the Spirituality Index of Well-Being. Research on Aging, 27(5), 556-577. DOI: https://doi.org/10.1177/0164027505277847

Gil, K., Radziwiłłowicz, P., Zdrojewski, T., Piwoński, J., Landowski, J., Wyrzykowski, B. (2006). Depresja jako czynnik ryzyka chorób układu sercowo-naczyniowego. Kardiologia Polska, 64, 526-531.

Guthrie, S. (2001). Why Gods? A cognitive theory. W: J. Andresen (ed.), Religion in Mind. Cognitive Perspectives on Religious Belief, Ritual, and Experience (s. 94-112). New York: Cambridge University Press.

Heszen-Niejodek, I. (2000). Teoria stresu psychologicznego i radzenia sobie. W: J. Strelau (red.), Psychologia. Podręcznik akademicki (T. 3, s. 465-492). Gdańsk: GWP.

Hobfoll, S.E. (1989). Conservation of Resources: A New Attempt at Conceptualizing Stress. American Psychologist, 44(3), 513-524. DOI: https://doi.org/10.1037/0003-066X.44.3.513

Kato, T. (2012). Development of the coping flexibility scale: evidence for the coping flexibility hypothesis. Journal of Counseling Psychology, 59(2), 262-273. DOI: https://doi.org/10.1037/a0027770

Kato, T. (2015). The Dual-Process Theory: New Approach to Coping Flexibility. W: M.A. Basińska (red.), Coping Flexibility with Stress in Health and in Disease. Elastyczne radzenie sobie ze stresem w zdrowiu i w chorobie (s. 19-37). Bydgoszcz: Wydawnictwo UKW.

Koening, H.G. (2008). Concerns about measuring "spirituality" in research. Journal of Nervous and Mental Disease, 196(5), 349-355. DOI: https://doi.org/10.1097/NMD.0b013e31816ff796

Krause, N. (2011). Religion and health: Making sense of a disheveled literature. Journal of Religion and Health, 50, 20-35. DOI: https://doi.org/10.1007/s10943-010-9373-4

Kruczek, A., Basińska, M.A., Grzankowska, I. (2019). Temperamental determinants of coping flexibility in adolescents. Advances in Psychiatry and Neurology/Postępy Psychiatrii i Neurologii, 28(1), 4-20. DOI: https://doi.org/10.5114/ppn.2019.84354

Kwon, P. (2002). Hope, Defence Mechanisms, and Adjustment: Implications for False Hope and Defensive Hopelessness. Journal of Personality, 70(2), 207-232.

DOI: https://doi.org/10.1111/1467-6494.05003

Lambiase, M.J., Kubzansky, L.D., Thurston, R.C. (2015). Positive psychological health and stroke risk: The benefits of emotional vitality. Health Psychology, 34(10), 1043-1046.

DOI: https://doi.org/10.1037/hea0000228

Lazarus, R.S., Folkman, S. (1984). Stress, Appraisal and Coping. New York: Springer.

Levenson, M.R., Aldwin, C.M. (2013). Mindfulness as religious practice. W: R.F. Paloutzian, C.L. Park (eds.), Handbook of the Psychology of Religion and Spirituality (s. 580-594). New York: Guilford Press.

Łaguna, M., Trzebiński, J., Zięba, M. (2005). Kwestionariusz Nadziei na Sukces KNS. Podręcznik. Warszawa: Pracownia Testów Psychologicznych PTP. 
Łuszczyńska, A., Cieślak, R. (2009). Mediated effects of social support for healthy nutrition: Fruit and vegetable intake across 8 months after myocardial infarction. Behavioral Medicine, 35(1), 30-37. DOI: https://doi.org/10.3200/BMED.35.1.30-38

MacDonald, D.A. (2000). Spirituality: Description, Measurement, and Relation to the Five Factor Model of Personality. Journal of Personality, 68(1), 153-197.

DOI: https://doi.org/10.1111/1467-6494.t01-1-00094

Masters, K.S. (2008). Mechanisms in the relation between religion and health with emphasis on cardiovascular reactivity to stress. Research in the Social Scientific Study of Religion, 19, 91-116. DOI: https://doi.org/10.1163/ej.9789004166462.i-299.29

McCollough, M.E., Willoughby, B. (2009). Religion, Self-Regulation, and Self-Control: Associations, Explanations, and Implications. Psychological Bulletin, 135(1), 69-93.

DOI: https://doi.org/10.1037/a0014213

McIntosh, D.N. (1995). Religion as schema, with implications for the relation between religion and coping. The International Journal for the Psychology of Religion, 5(1), 1-16.

DOI: https://doi.org/10.1207/s15327582ijpr0501_1

Moos, R.H., Schaefer, J.A. (1993). Coping resources and processes: Current concepts and measures. W: L. Goldberger, S. Breznitz (eds.), Handbook of Stress: Theoretical and Clinical Aspects (s. 234-257). New York: Free Press.

Mróz, J. (2014). Znaczenie zasobów osobistych dla zachowań i przeżyć związanych z pracą pielęgniarek. Problemy Higieny i Epidemiologii, 93(3), 731-736.

Mudyń, K. (2003). Czy można mieć zasoby, nie mając do nich dostępu? Problem dostępności zasobów. W: Z. Juczyński, N. Ogińska-Bulik (red.), Zasoby osobiste i społeczne sprzyjające zdrowiu jednostki (s. 63-77). Łódź: Wydawnictwo UŁ.

Nelson, J.M. (2009). Psychology, religion, and spirituality. W: J.M. Nelson (ed.), Psychology, Religion, and Spirituality (s. 311-345). New York: Springer.

Oman, D., Thoresen, C.E., Park, C.L., Shaver, P.R., Hood, R.W., Plante, T.G. (2012). Spiritual modeling self-efficacy. Psychology of Religion and Spirituality, 4(4), 278-297.

DOI: https://doi.org/10.1037/a0027941

Opuchlik, K., Wrzesińska, M., Kocur, J. (2009). Ocena poziomu stylów radzenia sobie ze stresem i poczucia umiejscowienia kontroli zdrowia u osób z chorobą niedokrwienną serca i nadciśnieniem tętniczym. Psychiatria Polska, 43(2), 235-245.

Ozorak, E.W. (2005). Cognitive approaches to religion. W: R.F. Paloutzian, C.L. Park (eds.), The Handbook of the Psychology of Religion and Spirituality (s. 253-273). New York: Guilford.

Park, C.L. (2012). Meaning, spirituality, and growth: Protective and resilience factors in health and illness. W: A.S. Baum, T.A. Revenson, J.E. Singer (eds.), Handbook of Health Psychology (s. 405-430). New York: Taylor \& Francis.

Piedmont, R.L. (1999). Does Spirituality Represents the Sixth Factor of Personality? Spiritual Transcendence and the Five-Factor Model. Journal of Personality, 67(6), 985-1013.

DOI: https://doi.org/10.1111/1467-6494.00080

Piedmont, R.L. (2005). The role of personality in understanding religious and spiritual constructs. W: R.F. Paloutzian, C.L. Park (eds.), Handbook of the Psychology of Religion and Spirituality (s. 253-273). New York: Guilford Press.

Piórowska, A., Banasik, A. (2015). Nadzieja a elastyczne radzenie sobie ze stresem u policjantów. W: M.A. Basińska (red.), Coping Flexibility with Stress in Health and in Disease. Elastyczne radzenie sobie ze stresem $w$ zdrowiu $i$ w chorobie (s. 187-208). Bydgoszcz: Wydawnictwo UKW.

Poprawa, R. (1996). Zasoby osobiste w radzeniu sobie ze stresem. W: G. Dolińska-Zygmunt (red.), Elementy psychologii zdrowia (s. 101-136). Wrocław: Wydawnictwo Uniwersytetu Wrocławskiego. 
Ryff, C.D., Singer, B.H. (2008). Know thyself and become what you are: A eudaimonic approach to psychological well-being. Journal of Happiness Studies, 9, 13-39.

DOI: https://doi.org/10.1007/s10902-006-9019-0

Shen, B.J., Myers, H.F., McCreary, C.P. (2006). Psychosocial predictors of cardiac rehabilitation quality-of-life outcomes. Journal of Psychosomatic Research, 60(1), 3-11.

DOI: https://doi.org/10.1016/j.jpsychores.2005.06.069

Skrzypińska, K. (2012). Granice duchowości - perspektywa pierwsza. Roczniki Psychologiczne, 15(1), 75-96.

Snyder, Ch.R. (2000). Handbook of Hope: Theory, Measures \& Applications. San Diego: Academic Press.

Snyder, Ch.R. (2002). Hope theory: Rainbows in the mind. Psychological Inquiry, 13(4), 249-275. DOI: https://doi.org/10.1207/S15327965PLI1304_01

Snyder, Ch.R., Pulvers, K.M. (2001). Dr. Seuss, the coping machine, and "Oh, the Places You'll Go". W: Ch.R. Snyder (ed.), Coping with Stress: Effective People and Processes (s. 3-29). Oxford: Oxford University Press.

Sołtys, M. (2015). Elastyczne radzenie sobie ze stresem a subiektywna ocena stanu zdrowia wśród osób chorych przewlekle: pośrednicząca rola dobrostanu duchowego oraz wieku. W. M. Basińska (red.), Coping Flexibility with Stress in Health and in Disease. Elastyczne radzenie sobie ze stresem $w$ zdrowiu $i$ w chorobie (s. 123-140). Bydgoszcz: Wydawnictwo UKW.

Strike, P.C., Steptoe, A. (2004). Psychosocial factors in the development of coronary artery disease. Progress in Cardiovascular Diseases, 46(4), 337-347.

DOI: https://doi.org/10.1016/j.pcad.2003.09.001

Szwajca, K. (2014). Dyskurs na temat resilience - konteksty i aspekty praktyczne. Psychoterapia, $168,99-107$.

Trzebińska, E. (2008). Psychologia pozytywna. Warszawa: Wydawnictwa Akademickie i Profesjonalne.

Trzebiński, J., Zięba, M. (2003). Kwestionariusz nadziei podstawowej BHI-12. Warszawa: Pracownia Testów Psychologicznych PTP.

Trzebiński, J., Zięba M., (2004). Basic hope as a world-view: An outline of concept. Polish Psychological Bulletin, 35(3), 173-182.

\section{SUMMARY}

The aim of this study was to analyze the relationship between personal resources (hope for success and spiritual well-being) and flexibility in coping with stress in cardiac patients and to check whether personal resources and duration of the disease are predictors of flexibility in coping with stress in this group. The participants of the study were 120 cardiac patients ( 72 men and 48 women) aged 29-75. The study used the Questionnaire of Hope for Success (KNS), the Indicator of Spiritual Well-Being and the Questionnaire of flexibility in coping with stress (KERS-14). The results show that there is a statistically significant relationship between personal resources and flexibility in coping. Each of the personal resources (hope for success and spiritual well-being) positively correlates with each of the dimensions of flexible coping. The analysis showed that personal resources play a predictive role for flexibility in coping with stress. patients

Keywords: personal resources; hope; spiritual well-being; flexibility in coping; cardiac 